\title{
The quality of semen among a sample of young, healthy men from Lower Silesia (AndroLS)
}

\author{
Jakość nasienia u młodych, zdrowych mężczyzn, mieszkańców Dolnego Śląska \\ (AndroLS)
}

\section{Marek Mędraśi, 2, Felicja Lwow ${ }^{3}$, Pawet Jóźków ${ }^{1}$, Leszek Szmigiero ${ }^{4}$, Aleksandra Zagrodna ${ }^{5}$, Ewa Zagocka ${ }^{6}$, Małgorzata Słowińska-Lisowska ${ }^{5}$}

\author{
${ }^{1}$ Department of Sports Medicine, University School of Physical Education, Wroclaw, Poland \\ ${ }^{2}$ Department of Endocrinology, Diabetology E Isotope Treatment, Wroclaw Medical University, Wroclaw, Poland \\ ${ }^{3}$ Department of Health Promotion, University School of Physical Education, Wroclaw, Poland \\ ${ }^{4}$ Department of Nucleic Acid Biochemistry, Medical University of Lodz, Lodz, Poland \\ ${ }^{5}$ Department of Nutrition, University School of Physical Education, Wroclaw, Poland \\ ${ }^{6}$ Andrological Laboratory, Male Infertility Diagnostic Centre, Wroclaw, Poland
}

\begin{abstract}
Introduction: Contrary to other parts of the continent, little information is available regarding semen quality among subjects from central and eastern Europe.

Material and methods: We evaluated semen profiles among a sample of men from an industrialised region of Poland. We directly invited 5000 healthy inhabitants of the region (aged 18-35 years; with unchecked fecundity) to participate in the study. Among the 500 who were eligible and willing to participate, we acquired detailed information and semen and blood samples from 177 subjects.

Results: Semen volume, sperm concentration, and total sperm count were, respectively, (mean \pm SD): $3.1 \pm 1.5 \mathrm{ml}, 60 \pm 44 \times 10^{6} / \mathrm{ml}$ and $170 \pm 137 \times 10 \% \mathrm{ml}$. Percentage of normal forms was $14.7 \pm 6.5 \%$.

Conclusions: Due to the relatively low sperm motility (mean \pm SD: $54 \pm 16 \%$ ) and vitality (mean \pm SD: $60 \pm 15 \%$ ) values, these variables require special attention during routine evaluations. The WHO 2010 criteria for these two parameters were met in only $60 \%$ and $66 \%$ of the samples, respectively. Further studies on men with different educational levels, social environments, or living conditions are needed to confirm our results. (Endokrynol Pol 2017; 68 (6): 668-675)
\end{abstract}

Key words: sperm quality parameters, semen analysis, epidemiology, general population

\section{Streszczenie}

Wstęp: Odmiennie niż w przypadku innych części kontynentu dysponujemy niewielką ilością informacji dotyczących jakości nasienia w populacjach centralnej i wschodniej Europy.

Materiał i metody: $\mathrm{W}$ badaniu ocenialiśmy próbki nasienia młodych, zdrowych mężczyzn. Zaproszenia skierowaliśmy do 5000 mieszkańców uprzemysłowionego regionu Polski w wieku 18-35 lat, o nieznanym stanie płodności. Spośród 500 mężczyzn, którzy wstępnie zgodzili się na udział w badaniu i spełniali kryteria włączenia, pełne informacje (próbki nasienia i krwi) uzyskaliśmy w 177 przypadkach. Wyniki: Objętość nasienia, koncentracja plemników i liczba plemników u badanych mężczyzn wynosiły odpowiednio (średnia \pm odchylenie standardowe): $3.1 \pm 1.5 \mathrm{ml}, 60 \pm 44 \times 10^{6} / \mathrm{ml} \mathrm{i} 170 \pm 137 \times 10^{6} / \mathrm{ml}$. Odsetek form o prawidłowej budowie wynosił $14.7 \pm 6.5 \%$. Wnioski: Ze względu na relatywnie małą ruchliwość (średnia \pm odchylenie standardowe: $54 \pm 16 \%$ ) i żywotność plemników (średnia \pm odchylenie standardowe: $60 \pm 15 \%$ ) wydaje się, że cechy te wymagają szczególnej uwagi podczas rutynowej diagnostyki. Kryteria normy wg WHO (2010 r.) w zakresie dwóch wspomnianych wyżej parametrów spełniało w naszym badaniu odpowiednio tylko $60 \%$ i $66 \%$ próbek. Uzyskane wyniki wymagają potwierdzenia u mężczyzn o różnym: stopniu wykształcenia, uwarunkowaniach socjalnych i miejscu zamieszkania. (Endokrynol Pol 2017; 68 (6): 668-675)

Słowa kluczowe: parametry jakości nasienia, badanie nasienia, epidemiologia, populacja ogólna

\section{Introduction}

There is an ongoing discussion regarding the decline of the number and quality of spermatozoa in humans [1-3]. This phenomenon is of special importance in the context of worrisome demographic trends in developed countries and because male factors may play a role in
$40 \%$ of infertile couples [4]. Some studies show that in Europe, there are areas in which only $23 \%$ of young men have optimal sperm concentration and sperm morphology (with regard to fecundity) [5].

Evaluating data on sperm quality in specific regions and comparing them with 'normal values' have some limitations. For example, some authors have suggested 
the presence of a west-east gradient in the quality of sperm across Europe, with higher sperm parameters in men from Finland, Estonia, and Lithuania and lower parameters in men living in Denmark, Germany, and Norway [6-8]. At the same time, sperm characteristics may reveal geographic variety even within one country [9-11].

There is little information on sperm parameters in healthy men from the central and eastern parts of Europe. We suspect that not only personal barriers (embarrassment) but also cultural and religious obstacles prevent potential candidates from participation in such studies [12]. The abolition of compulsory military conscription/draft in the majority of European countries has limited access to young, male populations. However, several andrological surveys are biased by being confined to subjects recruited either by infertility clinics/andrology units or by being financially rewarded $[7,9,13]$.

The goal of our study was to evaluate sperm parameters in a sample of young, unscreened, healthy men with unknown fertility living in Lower Silesia (a region of Poland).

\section{Materials and methods}

\section{Ethical approval}

The project associated with the study entitled Andrological Status of Young Men in Lower Silesia (AndroLS) was approved by the local Bioethics Committee. All procedures were conducted in compliance with the Declaration of Helsinki for human subjects and the European Communities Council Directive of 24 November 1986 (86/609/EEC).

\section{The base population}

We performed the investigation in young, healthy men aged 18-35 years, who came from a homogenous population of Lower Silesia (Poland). The region of Lower Silesia lies in southern Poland (bordering Germany and the Czech Republic) and covers an area of $19,947 \mathrm{~km}^{2}$. It has $2,908,000$ inhabitants (100\% Caucasian), and the population density is 146 persons per $\mathrm{km}^{2}$. The region is the second most urbanised voivodeship in Poland, with $69.3 \%$ of people living in urban environments. People under 65 years of age constitute $84.5 \%$ of the population. Life expectancy for men is estimated at 73.1 years, and there is an actual man/woman ratio of 100/108. The percentage of people (aged 15-64 years) with higher education is $24.5 \%$, and the number of students in 2014/2015 was more than 136,000 (36,607 graduates/year). Agricultural land constitutes $60 \%$ of the area, while forests constitute $30 \%$ of the area. Lower Silesia is one of the most industrialised regions in Poland. The regional gross domestic product (GDP) reaches $74 \%$ of the European average (http://stat.gov. pl/vademecum/vademecum_dolnoslaskie/portret_wojewodztwa/wojewodztwo_dolnoslaskie.pdf).

\section{Recruitment procedure}

We announced the study through the following media: fliers; notices; messages via Facebook, Twitter, and Instagram; and personal communication to university students, societies, and clubs in the region. We directly contacted more than 5000 men.

Those who responded to the invitations $(n=500)$ were asked to fill out the questionnaires covering medical history, nutritional habits (recall diary of the last seven days), and physical activity (IPAQ, last-seven-day recall) [14]. We did not enrol subjects who were being diagnosed or treated because of andrological pathology, who had undergone urogenital surgery, who had known or suspected fertility issues, who had chronic diseases, or who received medications that could interfere with hormonal or seminal evaluation. Although we did not offer any financial incentive to the volunteers, the benefit for those who decided to participate in the study was the knowledge of their andrological and nutritional status.

From among 300 eligible men, we managed to gather blood samples and completed questionnaires from 203 subjects. The last stage involved collection of sperm samples during appointed visits to the universityaffiliated laboratories. Appointments were scheduled in late autumn and winter. Eventually, all data was available for 177 subjects.

In the final step, we excluded men with an absence of spermatozoa in sperm samples as well as those with hormonal values beyond the normal range (1.7-8.6 $\mathrm{mIU} / \mathrm{ml}$ for luteinising hormone [LH], $1.5-12.4 \mathrm{mIU} / \mathrm{ml}$ for follicle-stimulating hormone [FSH], and 2.49-8.36 $\mathrm{ng} / \mathrm{ml}$ for total testosterone). They were referred for diagnostic procedures and could not be followed further (in some of the excluded cases Klinefelter syndrome was suspected). A total of 169 subjects met all of the above criteria.

\section{Enrolled participants}

Our subjects were representative of men entering the reproductive period (Tab. I).

The median age of the enrolled subjects was 24 years. The participants were lean and did not follow any specific diets (data not presented). The mean LH and FSH levels in the group were 5.1 and $4.0 \mathrm{mIU} / \mathrm{ml}$, respectively. The mean total testosterone level was $6.0 \mathrm{ng} / \mathrm{ml}$.

All of the enrolled men had completed secondary school and were either continuing their education or 
Table I. Participant characteristics $(n=169)$

Tabela I. Charakterystyka uczestników badania $(n=169)$

\begin{tabular}{lll}
\hline Variable & Mean \pm SD & Median (5-95) \\
\hline Age (years) & $24.6 \pm 3.6$ & $24.0(19.4-32.0)$ \\
\hline BMl $\left(\mathrm{kg} / \mathrm{m}^{2}\right)$ & $24.0 \pm 2.8$ & $23.8(19.9-29.0)$ \\
\hline $\mathrm{LH}(\mathrm{mlU} / \mathrm{ml})$ & $5.1 \pm 2.2$ & $4.6(2.3-9.4)$ \\
\hline FSH (mlU/ml) & $4.0 \pm 2.5$ & $3.3(1.4-9.1)$ \\
\hline T (ng/ml) & $6.0 \pm 2.0$ & $5.9(3.4-9.0)$ \\
\hline Social and lifestyle characteristics & \\
\hline & $\mathrm{n}(\%)$ & \\
\hline Education (> 12 years) & $169(100)$ \\
\hline Regular physical activity & $29(17.1)$ \\
\hline Current smokers (\%) & $24(14.2)$ \\
\hline Mother smoking during pregnancy (\%) & $8(4.7)$ \\
\hline Alcohol drinking* & $155(91.7)$ \\
\hline Taking medications & $32(18.9)$ \\
\hline
\end{tabular}

SD - standard deviation; 5-95 $-5^{\text {th }}-95^{\text {th }}$ percentiles; BMI - body mass index; $\mathrm{LH}$ - luteinising hormone; FSH - follicle-stimulating hormone; $\mathrm{T}$ - total testosterone. *Beer, wine, or spirits in the amount equivalent to at least $50 \mathrm{~g}$ of ethanol per week

had graduated from universities. Their level of physical activity was slightly lower than that previously reported for European countries [15]. A minority of them smoked cigarettes, which was an observation that was concordant with the downward trend in male smoking observed in recent years in Poland [16]. More than $90 \%$ of the men reported drinking alcohol, and $20 \%$ of the men took medications known to not interfere with hormonal and seminal parameters. Only a few men revealed that their mothers smoked while pregnant with them.

\section{Semen analysis}

The collection of semen for diagnostics and semen analysis was consistent with the latest guidelines of the World Health Organisation [17].

Semen samples were collected in the andrology laboratory-associated room. The samples were obtained by masturbation, ejaculated into a sterile plastic (non-toxic for spermatozoa) container, and placed in an incubator $\left(37^{\circ} \mathrm{C}\right)$ during liquefaction.

The ejaculation abstinence time and the time between sample collection and analysis were recorded in each patient's personal lab report.

All semen samples were analysed by a single experienced medical analyst according to the World Health Organisation (WHO) 2010 diagnostician laboratory manual and using the Sperm Class Analyzer (SCA; CASA System MICROPTIC S.L., Barcelona, Spain). The performance of the laboratory is continually evaluated through external quality assessment (EQAS Labquality, Helsinki, Finland; www.labquality.fi).

Semen analysis included measurements of $\mathrm{pH}$, sperm count, sperm concentration, and peroxidasepositive cells, as well as an evaluation of the motility, vitality, and morphology of sperm.

Semen volume was estimated by the weighing method ( $1 \mathrm{~g}$ of weight equals $1 \mathrm{ml}$ of volume). Semen $\mathrm{pH}$ was measured with $\mathrm{pH}$ indicator strips (Merck, Germany). Motility of spermatozoa was evaluated using computer-aided sperm analysis (SCA). The procedure was performed at $37^{\circ} \mathrm{C}$ with a heated microscope stage. Sperm movement was graded as rapid and slow progressive motility, non-progressive motility, or immotility. The number of spermatozoa was assessed with SCA and verified manually using the improved Neubauer haemocytometer (Sigma-Aldrich, Munich, Germany) (examination with phase-contrast optics at $\times 400$ magnification). Eosin-nigrosin stain (VitalScreen test, FertiPro N.V., Belgium) was used for the assessment of spermatozoa vitality. Each slide was examined with bright-field optics at $\times 1000$ magnification and oil immersion. The LeucoScreen test (FertiPro N.V., Belgium) was applied to detect peroxidase-positive leucocytes with the use of the improved Neubauer chamber (evaluation with phase-contrast optics at $\times 400$ magnification).

Sperm morphology was evaluated by SCA and was verified manually (Diff-Quik staining method, MICROPTIC S.L., Barcelona, Spain). Examinations were performed with a bright-field objective at $\times 1000$ magnification and oil immersion.

\section{Hormonal evaluation}

Blood sampling was carried out at 8:00 am. while fasting. Serum concentrations of FSH, LH, and total testosterone were determined by electrochemiluminescence (ECLIA) using the Elecsys system Cobas e 601 (Roche, Switzerland). The intra- and interassay coefficients of variation (CVs) and the limit of detection were, respectively, 2.6\%, 3.9\%, and < $0.100 \mathrm{mlU} / \mathrm{ml}$ for FSH; 0.9\%, $1.9 \%$, and $0.100 \mathrm{mlU} / \mathrm{ml}$ for $\mathrm{LH}$; and $5.3 \%, 6.3 \%$, and $0.025 \mathrm{ng} / \mathrm{ml}$ for total testosterone (T).

\section{Statistical methods}

The data were analysed using the SigmaPlot (Systat Software Inc., London, UK) statistics package, version 12.5. Continuous variables were first analysed for normal distribution using the Kolmogorov-Smirnoff test with the Lilliefors correction test. Almost all semen parameters exhibited a non-normal distribution, except motility grade a, which passed the normality test. Biochemical parameters describing the hormonal status of the participants, such as LH, FSH, and total testosterone, exhibited a normal distribution. Descriptive statistics are 
Table II. Semen parameters among the participants compared with 2010 WHO reference values

Tabela II. Parametry seminologiczne uczestników badania $w$ kontekście norm WHO z 2010 roku

\begin{tabular}{|c|c|c|c|}
\hline Variable & Mean \pm SD & Median (5-95) & $\begin{array}{l}\text { LRL* limits } \\
\text { according } \\
\text { to WHO } \\
2010\end{array}$ \\
\hline Semen volume (ml) & $3.1 \pm 1.5$ & $3.0(1.1-6.0)$ & 1.5 \\
\hline $\mathrm{pH}$ & $7.9 \pm 0.2$ & $7.9(7.7-8.4)$ & $>7.1$ \\
\hline $\begin{array}{l}\text { Leukocytes (106/ } \\
\text { ml) }\end{array}$ & $0.11 \pm 0.27$ & $0.0(0.0-0.49)$ & $<1$ \\
\hline $\begin{array}{l}\text { Time of liquefaction } \\
\text { (min) }\end{array}$ & $27.4 \pm 9.2$ & $25.0(15.0-47.5)$ & $\leq 60 \min$ \\
\hline $\begin{array}{l}\text { Sperm } \\
\text { concentration (106/ } \\
\text { ml) }\end{array}$ & $60 \pm 44$ & $52(7-152)$ & 15 \\
\hline $\begin{array}{l}\text { Total sperm count } \\
\text { (106/ejaculate) }\end{array}$ & $170 \pm 137$ & $145(20-405)$ & 39 \\
\hline $\begin{array}{l}\text { Motility (grade } \\
a, \%)\end{array}$ & $22.6 \pm 11.1$ & $22.0(5.5-43.0)$ & - \\
\hline $\begin{array}{l}\text { Motility (grade } \\
\text { b, \%) }\end{array}$ & $13.3 \pm 8.9$ & $12.0(4.0-23.0)$ & - \\
\hline $\begin{array}{l}\text { Motility (grade } \\
\mathrm{c}, \%)\end{array}$ & $18.3 \pm 6.4$ & $18.0(8.5-30.5)$ & - \\
\hline $\begin{array}{l}\text { Progressive motility } \\
\text { (grades } a+b, \%)\end{array}$ & $35.2 \pm 14.5$ & $36.0(12.0-59.5)$ & 32 \\
\hline $\begin{array}{l}\text { Total motility } \\
\text { (grades } a+b+ \\
\text { c, \%) }\end{array}$ & $53.8 \pm 16.4$ & $56.0(23.0-76.0)$ & 40 \\
\hline Vitality (\%) & $60.3 \pm 14.7$ & $62.0(34.0-80.5)$ & 58 \\
\hline Normal forms (\%) & $14.7 \pm 6.5$ & $14.0(4.5-26.5)$ & 4 \\
\hline
\end{tabular}

presented using untransformed data. All of the values are expressed as the mean \pm standard deviation (SD), as well as the median and $5^{\text {th }}$ and $95^{\text {th }}$ percentiles.

\section{Results}

The mean semen volume in our group of healthy, young men was $3.1 \mathrm{ml}$; the sperm concentration was $60 \times 10^{6} / \mathrm{ml}$; and the sperm count was $170 \times 10^{6} /$ ejaculate. Nearly $54 \%$ of the sperm were motile, and $60 \%$ of the spermatozoa were vital. Leukocytes were found at a mean concentration of $0.11 \times 10^{6} / \mathrm{ml}$ (Tab. II).

The mean and median of seven key sperm parameters in the studied subjects were within the reference limits established by the WHO in 2010 [17].

Although the percentage of vital sperm cells was within the normal range, the mean and median were close to the lower limit (Tab. II). Interestingly, we noticed
Table III. Sperm morphology among the participants Tabela III. Budowa plemników u uczestników badania

\begin{tabular}{lll}
\hline Morphology characteristics & Mean \pm SD & Median (5-95) \\
\hline Pathological forms (\%) & $84.8 \pm 8.8$ & $86.0(73.0-95.0)$ \\
\hline Sperm with an amorphous head (\%) & $54.8 \pm 6.9$ & $54.0(44.0-65.5)$ \\
\hline Sperm with a round head (\%) & $3.9 \pm 8.7$ & $3.0(0.0-9.5)$ \\
\hline Sperm with a tapered head (\%) & $2.2 \pm 3.4$ & $1.0(0.0-8.5)$ \\
\hline Double-headed sperm (\%) & $0.3 \pm 0.6$ & $0.0(0.0-2.0)$ \\
\hline Sperm with a microcephalic head (\%) & $2.1 \pm 2.4$ & $2.0(0.0-6.0)$ \\
\hline Sperm with a macrocephalic head (\%) & $2.9 \pm 2.2$ & $3.0(0.0-7.0)$ \\
\hline Head with cytoplasmic droplets (\%) & $0.1 \pm 0.2$ & $0.0(0.0-1.0)$ \\
\hline Sperm with a vacuolated head (\%) & $3.7 \pm 1.8$ & $3.0(1.0-7.0)$ \\
\hline $\begin{array}{l}\text { Sperm with an abnormal middle- } \\
\text { piece (\%) }\end{array}$ & $7.6 \pm 4.1$ & $7.0(2.0-14.5)$ \\
\hline Sperm with an abnormal tail (\%) & $8.1 \pm 4.3$ & $7.0(2.0-16.0)$ \\
\hline SD - standard deviation; 5-95 - 5 ${ }^{\text {th }-95^{\text {th }}}$ percentiles &
\end{tabular}

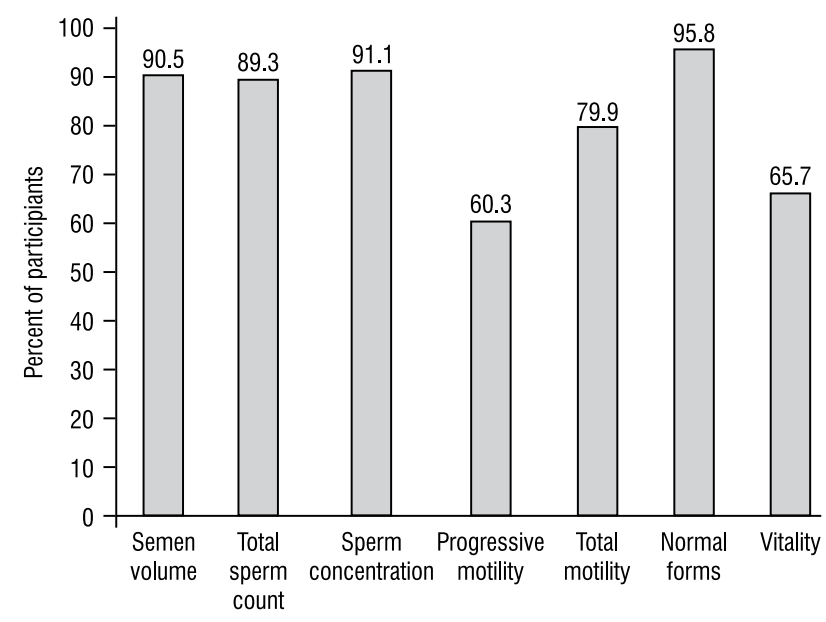

Figure 1. Percentage of participants with specific semen parameters within the 2010 WHO reference ranges

Rycina 1. Procent uczestników badania, u których poszczególne parametry seminologiczne spetniaty kryteria WHO z 2010 roku

a relatively high percentage of pathological spermatozoa in the studied samples (mean 85\%) (Tab. III).

When we compared the results of our sample with the 2010 WHO reference values, we found that the parameter that best matched the WHO criteria was the percentage of normal forms (96\%). In contrast, the rate of progressive motility of spermatozoa (grade $a+b$ ) suggested by the WHO was found in only $60 \%$ of the studied samples (Fig. 1).

All seven WHO criteria for normal sperm were met in $50 \%$ of the samples (Fig. 2). Nearly $9 \%$ of the studied men had either one, two, or three parameters beyond the reference limits. 


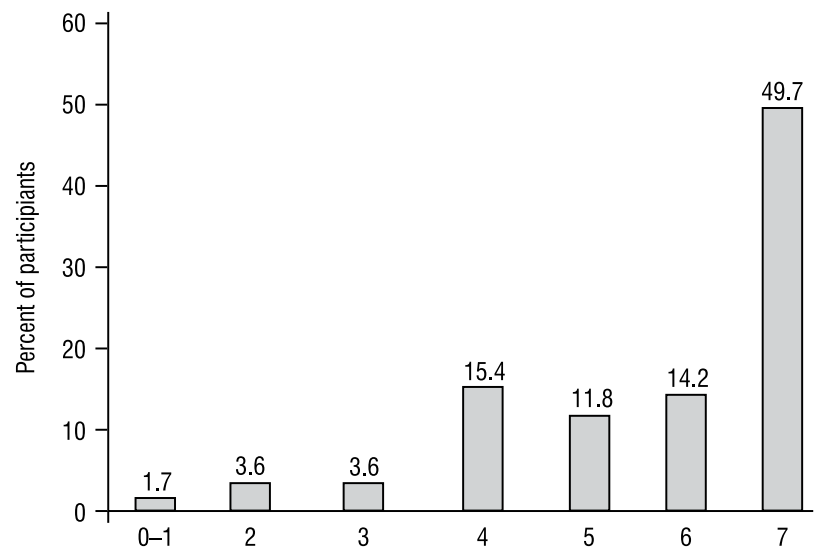

Figure 2. Percentages of participants who met different numbers of WHO 2010 semen quality criteria (semen volume, sperm concentration, total sperm number, total motility, progressive motility, vitality, morphology)

Rycina 2. Procent uczestników badania, u których określona liczba parametrów seminologicznych spetniała kryteria WHO z 2010 roku (objętość nasienia, koncentracja plemników, liczba plemników, ruchliwość plemników, ruch postępowy plemników, żywotność plemników, prawidłowa budowa plemników)

\section{Discussion}

The present investigation aimed to assess sperm parameters in young, healthy men with unknown fertility status living in an industrialised region of Poland.

Although studies are regularly performed in Scandinavia $[5,6,18]$, similar research is rarely conducted in Poland/eastern Europe. One exception was a study on semen profiles among 202 subjects aged $18-35$ years from two academic cities in Poland. The authors found that the mean sperm concentration was between 41 and $50 \times 10^{6} / \mathrm{ml}$ (markedly lower than that in Lower Silesia), with a mean sperm count ranging between 121 and 209 x $10 \%$ ejaculate. The mean percentage of sperm with progressive motility was $42-48 \%$, compared with $35 \%$ in our setting. A drawback to the interpretation of these data is that the participants were recruited through an andrology unit and fertility clinics [9]. This method may result in different forms of selection [19]. One cannot exclude a higher attendance rate of subjects with congenital pathology, with early childhood disturbances (cryptorchidism), or who sustained gonadal trauma.

In another investigation, authors from the neighbouring Czech Republic reported on the quality of sperm in a population sample of 18-year-old men $(\mathrm{n}=$ 272). They analysed subgroups living in environments with different levels of air pollution. After pooling, the studied men were younger, smoked cigarettes more often, and drank alcohol less frequently than our subjects. Surprisingly, they had a median sperm concentration and total sperm count that were lower than those in our study (44 vs. $52 \times 10^{6} / \mathrm{ml}$ and 81 vs. $145 \times 10^{6} /$ ejaculate). Similarly, the median total motility and progressive motility were also lower ( 25 vs. $56 \%$ and 20 vs. $36 \%$ ). In contrast, young Czechs had a higher percentage of morphologically normal sperm (17 vs. 14\%). Such differences were present irrespective of the degree of exposure to air pollution [20].

A young population from across the border with Germany (those undergoing compulsory examination prior to military service; median age 18.5-19.5 years, median BMI 22, 53-55\% cigarette smokers) had a lower median sperm concentration ( $45-49$ vs. $52 \times 10^{6} / \mathrm{ml}$ ), sperm count (113-142 vs. $145 \times 10^{6} /$ ejaculate), and normal morphological forms (8.0-8.5\% vs. $14 \%)$. In contrast to Czech citizens, motile sperm were found in $68-82 \%$ of Germans vs. only $56 \%$ of Poles [7].

A recruitment protocol similar to that used in our study was applied by Spanish researchers [21, 22]. Unlike our subjects, the Spanish participants were financially compensated with either $20 €$ or a $50 €$ gift card. In Murcia (Spain), the enrolled subjects were younger and leaner than our participants (mean age: 20.4 years, mean BMI: 23.7). The sperm analysis was conducted using the same criteria applied in our study [17]. The Spaniards had a lower median sperm concentration (43 vs. $\left.52 \times 10^{6} / \mathrm{ml}\right)$ and a lower median sperm count (121 vs. $145 \times 10^{6} /$ ejaculate). However, total sperm motility (progressive and non-progressive) was higher than that in our study subjects (57 vs. 56\%) [22]. Furthermore, the men from Almeria were younger (mean 21 years) but only slightly leaner (mean BMI 24) than the men in our study. They had a similar median sperm concentration (51 vs. $52 \times 10^{6} / \mathrm{ml}$ ) and a higher median sperm count ( 149 vs. $145 \times 10^{6} /$ ejaculate). Again, total sperm motility was higher than that in our subjects (60 vs. $56 \%$ ) [21].

The mean sperm concentration in men from Lower Silesia was lower than that in army recruits from Finland, Estonia, and Norway; however, it was higher than that in men from Denmark. To some extent, this finding was in accordance with the hypothesis of an east-west gradient in semen quality, which suggests a relationship between local testicular cancer risk and semen quality [6]. Accordingly, the cancer risk in Poland was estimated to be lower than in Denmark and higher than in Estonia [23]. However, the mean total sperm counts were higher in Finland, Estonia, Norway, and Denmark than in Lower Silesia, and the percentage of morphologically normal sperm was lower than in our region. The median sperm motility was also higher in the aforementioned countries than in our region (66-75 vs. $56 \%$ ) [6].

Valuable datasets were obtained during mandatory medical examinations of young Danish men in the 
period 1996-2010. In this cohort, there were 4867 enrolled subjects aged 18-22 years (median age 19 years) with a BMI between 19 and 28 (median 22). Among the described men, $42 \%$ were cigarette smokers (vs. $24 \%$ in our study). Of note, $38 \%$ of the subjects' mothers smoked during pregnancy, compared with $8 \%$ in our cohort. The Danish men compared with the men from our sample had a lower median sperm concentration ( 45 vs. $52 \times 10^{6} / \mathrm{ml}$ ), sperm count (143 vs. $145 \times 10^{6} \%$ (ejaculate), and percentage of morphologically normal sperm (6 vs. 14\%). They also had a higher progressive sperm motility (59 vs. $36 \%$ ) and total motility (68 vs. $56 \%$ ) [5].

The results of studies from other continents show marked differences compared with our findings. Participants in the Rochester Young Men's Study (USA), whose median age was even younger (19.6 years) and whose BMIs were similar to those of our subjects $(58 \%$ under $25 \mathrm{~kg} / \mathrm{m}^{2}$ ), had a higher median sperm concentration ( $\left.53 \mathrm{vs.} 52 \times 10^{6} / \mathrm{ml}\right)$ and percentage of spermatozoa with progressive motility (60 vs. 36\%) and a lower median percentage of morphologically normal forms (8vs. 14\%) [24]. The authors of one of the most recently published papers collected samples from college students in China. They recruited 794 young men (median age 20 years) whose median sperm concentration and total sperm count appeared to be higher than those in our group (54 vs. $52 \times 10^{6} / \mathrm{ml}$ and 184 vs. $145 \times 10^{6} /$ /ejaculate, respectively). The median progressive motility and total motility were $55 \%$ and $88 \%$, respectively, compared with $35 \%$ and $53 \%$ in our cohort. However, the median percentage of morphologically normal sperm was lower ( $8 \%$ vs. $14 \%$ ). Although the prevalence of cigarette smoking was similar between our cohorts, the participants in the Chinese study drank alcohol less frequently (51\% vs. 91\%) [25].

Because we did not use confirmed fertility as a qualification for participation, we were curious whether this criterion would have had an impact on the outcomes of the study. The use of this criterion may have influenced the ranges accepted by the WHO [12]. We found that the means and medians of the seven key sperm parameters in men from Lower Silesia were within the WHO limits [17]. In view of these results, we suppose that the fact that our volunteers did not father children did not interfere significantly with the classification of sperm samples in this specific population.

However, six WHO criteria were met by only $63 \%$ of the participants in our investigation. Conversely, in the aforementioned Chinese study, $81 \%$ of the young students met six of the $2010 \mathrm{WHO}$ criteria [25].

The parameter that most often exceeded WHO reference ranges in our sample was the progressive motility of spermatozoa. We reiterate that in the recruit- ment protocol, we excluded men with chronic diseases, and we did not perform examinations during/after fever (factors associated with sperm motility) [7]. The median percentage of total motile spermatozoa was $54 \%$, and the percentage was within normal WHO limits in $80 \%$ of our subjects. However, the percentage of spermatozoa with progressive motility (grade $a+b)$ was below the reference range in $40 \%$ of the studied men. We cannot offer a clear explanation for this observation, although it may be because the WHO reference limits pertain to men who fathered children (who presumably have a higher percentage of motile sperm) [12]. At first glance, we supposed this finding could be due to alcohol intake. For example, participants in the Chinese study drank less frequently and had higher sperm motility [25]. Nevertheless, the findings of a cross-sectional study of 8344 healthy men (in Europe and the USA) demonstrated that alcohol intake was not associated with motility no any other semen variable [26]. The age of the participants was another factor that may have impacted motility in our investigation. Our study subjects were relatively old compared with those in the Spanish or Danish cohorts. However, young men from the Czech Republic were not only younger but they also drank alcohol less frequently than our study subjects, and they had even lower sperm motility [20].

Spermatogenesis is influenced by lifestyle and occupational exposures, but environmental factors cannot be neglected in this context $[27,28]$. For these reasons, it is important to know the extent to which location differences are reflected in the quality of sperm. Data from Spanish studies demonstrated that a higher level of industrialisation in a given region is associated with a higher ratio of oligozoospermia [29]. In accordance with the Spanish studies, other studies revealed that there were significant differences in the quality of semen in young men living in two German cities only $350 \mathrm{~km}$ apart. Men from Hamburg (West Germany) had different semen volumes, spermatozoa morphology, and sperm motility compared with men from Leipzig (East Germany) [7].

We can only hypothesise about other potential causes of the higher percentage of men with a reduced percentage of sperm with progressive motility in our sample. Lower Silesia has a relatively high level of radiation from natural sources (e.g. radon - 226Rn), and until 1997 the population in the area was moderately iodine-deficient. Parts of the region were exploited by the coal industry (until 1989), and parts are still being polluted by copper mining. In recent years, economic growth has relied on the development of automotive, electronics, and high-technology industries. The health risks of these economical changes in the region are unknown. 
Scholars from the U.S. have suggested that full fertility is present when more than $63 \%$ of spermatozoa are motile (although they admitted considerable variability in the measurements of this parameter) [30]. Whether the relatively low percentage of spermatozoa with progressive motility in the men we studied can exert effects on fecundity requires further investigation.

Additionally, we compared our results with the 1999 WHO reference values [31]. We found that samples from the present investigation also fell within the normal range according to the previously used limits for sperm volume $(\geq 2.0 \mathrm{ml})$, concentration $\left(\geq 20 \times 10^{6} /\right.$ $/ \mathrm{ml})$, total sperm number ( $\geq 40$ million), and leukocyte number $\left(<10^{6} / \mathrm{ml}\right)$. Interestingly, the mean percentage of spermatozoa with normal morphology $(15 \%)$ would be only slightly above the lower limit (14\%). However, similar to the comparisons with the present WHO ranges, the mean percentage of motile spermatozoa (grade $a+b$ ) in our samples $(35 \%)$ would be below the previously accepted lower limit, which was set at $\geq 50 \%$. A major difference in comparing our data with the current vs. 1999 WHO ranges is that the mean vitality $(60 \%)$ in our study is far below the lower range established in 1999 ( $\geq 75 \%)$.

Semen parameters depend on ejaculation abstinence, age, body mass, diet, physical activity, smoking status, caffeine/alcohol consumption, overuse of medications/psychostimulants, psychological distress, and previous medical history (e.g. the presence of varicocele). Additionally, maternal smoking during pregnancy, but not paternal habits, is inversely associated with sperm quality [4, 32-34]. The high percentage of reduced-quality semen together with the increasing age at which women decide to get pregnant may explain the reduced fecundity of populations from several countries $[32,35]$. In fact, the decline in sperm counts in recent decades has been reported in numerous studies $[3,36]$, although not all authors have observed this trend [5,37]. If the trend is real, the ageing process could be accelerated at the level of whole populations, which would create serious medical as well as socio-cultural threats to many societies (especially in ageing Europe).

The strength of our study is that semen samples were acquired and assessed according to the most recent WHO guidelines by a single, qualified technician. Thus, we avoided possible differences in readings that sometimes arise between laboratories. Potential intraindividual differences in the quality of semen samples have been demonstrated to not significantly affect epidemiological studies [38].

Unlike many other studies, we did not include subjects with diagnosed or suspected fertility problems (fertility clinic and andrology department patients).
The eight men who were excluded from the analysis had laboratory (but not clinical) features of hypogonadism. They were referred for further andrology examinations.

We want to emphasise that participation in our examination was neither compulsory nor associated with any financial incentive, an important difference from protocols of other larger trials.

The region from which volunteers were recruited is inhabited by a population with the same genetic background (nearly 100\% Caucasian). Unfortunately, we could not exclude potential influences of chromosome $Y$ microdeletions that are associated with altered sperm counts.

It is obvious that our results would be stronger if the response rate had been higher. We are aware that our results pertain best to men with a higher-level education, from urban localisations, and without specific exposures to chemicals or toxins. We have no data to assess a possible relationship between the latter factor and sperm parameters.

The subjects who decided to participate in our study may have been more interested in their health status than most men. We were unable to recruit volunteers from other environments, which should be the next step in researching this topic.

\section{Conclusions}

Our data provide information on sperm quality in a population that has not been described in the literature. Our study helps fill the gap in our knowledge of semen status in young, healthy, educated men from a specific region of Europe.

In view of these results, special attention should be paid to the high percentage of the population in the study setting with spermatozoa motility and vitality values that are below the $\mathrm{WHO}$ reference limits. We could not attribute these findings to age, BMI, or smoking or drinking habits of the subjects. We can only hypothesise that other unrecognised environmental factors influenced the study findings.

Further studies in men with different educational levels, social environments, or living conditions (e.g. urban vs. rural settings) are needed to identify and eventually follow possible changes in sperm quality in this region.

\section{References}

1. Carlsen E, Giwercman A, Keiding N, et al. Evidence for decreasing quality of semen during past 50 years. BMJ. 1992; 305(6854): 609-613, doi: 10.1136/bmj.305.6854.609, indexed in Pubmed: 1393072.

2. Skakkebaek NE, Rajpert-De Meyts E, Main KM. Testicular dysgenesis syndrome: an increasingly common developmental disorder with environmental aspects. Hum Reprod. 2001; 16(5): 972-978, indexed in Pubmed: 11331648 . 
3. Splingart C, Frapsauce C, Veau S, et al. Semen variation in a population of fertile donors: evaluation in a French centre over a 34-year period. Int J Androl. 2012; 35(3): 467-474, doi: 10.1111/j.1365-2605.2011.01229.x, indexed in Pubmed: 22150270.

4. Brugo-Olmedo S, Chillik C, Kopelman S. Definition and causes of infertility. Reprod Biomed Online. 2001; 2(1): 41-53, doi: 10.1016/s14726483(10)62187-6, indexed in Pubmed: 12537824.

5. Jørgensen N, Joensen UN, Jensen TK, et al. Human semen quality in the new millennium: a prospective cross-sectional population-based study of 4867 men. BMJ Open. 2012; 2(4), doi: 10.1136/bmjopen-2012-000990, indexed in Pubmed: 22761286

6. Jørgensen N, Carlsen E, Nermoen I, et al. East-West gradient in semen quality in the Nordic-Baltic area: a study of men from the genera population in Denmark, Norway, Estonia and Finland. Hum Reprod. 2002; 17(8): 2199-2208, doi: 10.1093/humrep/17.8.2199, indexed in Pubmed: 12151459 .

7. Paasch U, Salzbrunn A, Glander HJ, et al. Semen quality in sub-fertile range for a significant proportion of young men from the general German population: a co-ordinated, controlled study of 791 men from Hamburg and Leipzig. Int J Androl. 2008; 31(2): 93-102, doi: 10.1111/j.13652605.2007.00860.x, indexed in Pubmed: 18315714.

8. Punab M, Zilaitiene B, Jørgensen N, et al. Regional differences in semen qualities in the Baltic region. Int J Androl. 2002; 25(4): 243-252, doi: 10.1046/j.1365-2605.2002.00359.x, indexed in Pubmed: 12121574.

9. Kamieniczna M, Fraczek M, Malcher A, et al. Semen Quality, Hormonal Levels, and Androgen Receptor Gene Polymorphisms in a Population of Young Male Volunteers from Two Different Regions of Poland. Med Sci Monit. 2015; 21: 2494-2504, doi: 10.12659/MSM.893628, indexed in Pubmed: 26299772.

10. Swan SH, Brazil C, Drobnis EZ, et al. Study For Future Families Research Group. Geographic differences in semen quality of fertile U.S. males. Environ Health Perspect. 2003; 111(4): 414-420, indexed in Pubmed: 12676592 .

11. Swan SH, Elkin EP, Fenster L. The question of declining sperm density revisited: an analysis of 101 studies published 1934-1996. Environ Health Perspect. 2000; 108(10): 961-966, doi: 10.1289/ehp.00108961, indexed in Pubmed: 11049816.

12. Cooper TG, Noonan E, von Eckardstein S, et al. World Health Organization reference values for human semen characteristics. Hum Reprod Update. 2010; 16(3): 231-245, doi: 10.1093/humupd/dmp048, indexed in Pubmed: 19934213.

13. Jurewicz J, Radwan M, Sobala W, et al. Lifestyle and semen quality: role of modifiable risk factors. Syst Biol Reprod Med. 2014; 60(1): 43-51, doi 10.3109/19396368.2013.840687, indexed in Pubmed: 24074254

14. Craig CL, Marshall AL, Sjöström M, et al. International physical activity questionnaire: 12-country reliability and validity. Med Sci Sports Exerc. 2003; 35(8): 1381-1395, doi: 10.1249/01.MSS.0000078924.61453.FB, indexed in Pubmed: 12900694.

15. Haase A, Steptoe A, Sallis JF, et al. Leisure-time physical activity in university students from 23 countries: associations with health beliefs, risk awareness, and national economic development. Prev Med. 2004; 39(1): 182-190, doi: 10.1016/j.ypmed.2004.01.028, indexed in Pubmed: 15208001.

16. Jassem J, Przewoźniak K, Zatoński W. Tobacco control in Polandsuccesses and challenges. Transl Lung Cancer Res. 2014; 3(5): 280-285, doi: 10.3978/j.issn.2218-6751.2014.09.12, indexed in Pubmed: 25806312.

17. World Health Organization. WHO Laboratory Manual for the Examination and Processing of Human Semen. Geneva, 2010.

18. Axelsson J, Rylander L, Rignell-Hydbom A, et al. No secular trend over the last decade in sperm counts among Swedish men from the general population. Hum Reprod. 2011; 26(5): 1012-1016, doi: 10.1093/humrep/ der045, indexed in Pubmed: 21382832.

19. Tielemans E, Burdorf A, te Velde E, et al. Sources of bias in studies among infertility clients. Am J Epidemiol. 2002; 156(1): 86-92, doi: 10.1093/aje/ kwf011, indexed in Pubmed: 12076892.

20. Selevan SG, Borkovec L, Slott VL, et al. Semen quality and reproductive health of young Czech men exposed to seasonal air pollution. Environ Health Perspect. 2000; 108(9): 887-894, doi: 10.1289/ehp.00108887, indexed in Pubmed: 11017895
21. Fernandez MF Duran I Olea N et al Semen quality and reproductive hormone levels in men from Southern Spain. Int J Androl. 2012; 35(1) 1-10, doi: 10.1111/j.1365-2605.2010.01131 x indexed in Pubmed: 21332503.

22. Mínguez-Alarcón L, Chavarro JE, Mendiola J, et al. Physical activity is not related to semen quality in young healthy men. Fertil Steril. 2014; 102(4): 1103-1109, doi: 10.1016/j.fertnstert.2014.06.032, indexed in Pubmed: 25064411.

23. Richiardi L, Bellocco R, Adami HO, et al. Testicular cancer incidence in eight northern European countries: secular and recent trends. Cancer Epidemiol Biomarkers Prev. 2004; 13(12): 2157-2166, indexed in Pubmed: 15598775 .

24. Gaskins AJ, Mendiola J, Afeiche M, et al. Physical activity and television watching in relation to semen quality in young men. Br J Sports Med. 2015; 49(4): 265-270, doi: 10.1136/bjsports-2012-091644, indexed in Pubmed: 23380634

25. Yang H, Chen Q, Zhou N, et al. Lifestyles Associated With Human Semen Quality: Results From MARHCS Cohort Study in Chongqing, China. Medicine (Baltimore). 2015; 94(28): e1166, doi: 10.1097/ MD.0000000000001166, indexed in Pubmed: 26181561.

26. Jensen TK, Swan S, Jørgensen N, et al. Alcohol and male reproductive health: a cross-sectional study of 8344 healthy men from Europe and the USA. Hum Reprod. 2014; 29(8): 1801-1809, doi: 10.1093/humrep/ deu118, indexed in Pubmed: 24893607.

27. Homan GF, Davies M, Norman R. The impact of lifestyle factors on reproductive performance in the general population and those undergoing infertility treatment: a review. Hum Reprod Update. 2007; 13(3): 209-223, doi: 10.1093/humupd/dml056, indexed in Pubmed: 17208948.

28. Tsujimura A, Matsumiya $\mathrm{K}$, Takahashi T, et al. Effect of lifestyle factors on infertility in men. Arch Androl. 2004; 50(1): 15-17, doi: 10.1080/01485010490250551, indexed in Pubmed: 14660165.

29. López-Teijón M, Elbaile M, Alvarez JG. Geographical differences in semen quality in a population of young healthy volunteers from the different regions of Spain. Andrologia. 2008; 40(5): 318-328, doi: 10.1111/j.1439-0272.2008.00862.x, indexed in Pubmed: 18811923.

30. Guzick DS, Overstreet JW, Factor-Litvak P, et al. National Cooperative Reproductive Medicine Network. Sperm morphology, motility, and concentration in fertile and infertile men. N Engl J Med. 2001; 345(19): 1388-1393, doi: 10.1056/NEJMoa003005, indexed in Pubmed: 11794171.

31. World Health Organization. WHO Laboratory Manual for the Examination of Human Semen and Sperm-Cervical Mucus Interaction. 4th ed. Cambridge, UK, 1999.

32. Sharpe RM. Environmental/lifestyle effects on spermatogenesis. Philos Trans R Soc Lond B Biol Sci. 2010; 365(1546): 1697-1712, doi: 10.1098/ rstb.2009.0206, indexed in Pubmed: 20403879

33. Gaur DS, Talekar MS, Pathak VP. Alcohol intake and cigarette smoking: impact of two major lifestyle factors on male fertility. Indian J Pathol Microbiol. 2010; 53(1): 35-40, doi: 10.4103/0377-4929.59180, indexed in Pubmed: 20090219.

34. Liu CY, Chou YC, Chao JCJ, et al. The Association between Dietary Patterns and Semen Quality in a General Asian Population of 7282 Males. PLoS One. 2015; 10(7): e0134224, doi: 10.1371/journal.pone.0134224, indexed in Pubmed: 26218796.

35. Jensen TK, Jørgensen N, Asklund C, et al. Fertility treatment and reproductive health of male offspring: a study of 1,925 young men from the general population. Am J Epidemiol. 2007; 165(5): 583-590, doi: 10.1093/ aje/kwk035, indexed in Pubmed: 17182980.

36. Romero-Otero J, Medina-Polo J, García-Gómez B, et al. Semen Quality Assessment in Fertile Men in Madrid During the Last 3 Decades. Urology. 2015; 85(6): 1333-1338, doi: 10.1016/j.urology.2015.02.001, indexed in Pubmed: 25872697

37. Fisch H, Goluboff ET, Olson JH, et al. Semen analyses in 1,283 men from the United States over a 25-year period: no decline in quality. Fertil Steril. 1996; 65(5): 1009-1014, doi: 10.1016/s0015-0282(16)58278-8, indexed in Pubmed: 8612826.

38. Rylander L, Wetterstrand B, Haugen TB, et al. Single semen analysis as a predictor of semen quality: clinical and epidemiological implications. Asian J Androl. 2009; 11(6): 723-730, doi: 10.1038/aja.2009.64, indexed in Pubmed: 19823177. 